\title{
Discourse on 'Falsity' in Heritage Revitalization: The Beautification of Kali Besar Jakarta and Its Impacts on Historic Urban Landscape (HUL)
}

\author{
Euis Puspita Dewi ${ }^{1}$, Kemas Ridwan Kurniawan ${ }^{2}$ \\ ${ }^{1}$ Department of Architecture, Universitas Persada Indonesia, YAI \\ 2,Departement of Architecture, Universitas Indonesia \\ Email address of corresponding author: euis.puspitadewi@gmail.com
}

\begin{abstract}
This paper aims to raise the issue of "falsity" in Heritage Revitalization and how it impacts on values in Historic Urban Landscape. The object of the study is the process of revitalization carried out in Kali Besar in the Jakarta Old City Area based on Jakarta Governor's Instruction 2016, No. 101. To evaluate Kali Besar's revitalization planning, this study uses historical methods, especially those relating to aspects of urban space, social and revitalization policies. This study results the findings that the Revitalization of Kali Besar was not done through a good management plan and arranged with various changes as the cause. Beautification is still considered as the main foundation in the Kali Besar arrangement. Historic Urban Landscape must be the main references in the process of revitalizing the Kali Besar area and to produce a mature management plan.
\end{abstract}

(C) 2018 IJBESR. All rights reserved.

Keywords: Beautification, Falsity, Heritage, Landscape, Revitalization.Instructions.

\section{Introduction}

In the 17th century, Kali Besar was a canal that had important significance for the city and the plural society of Batavia with its various activities, starting as a means of transportation, economy, segregation and recreation, representation of lifestyle or even a symbol of glory [1]. Although it had experienced environmental damage in the 18th century, the region was once again passionate as a commercial and trading area in the 19th and 20th century. However, until now, Kali Besar continues to experience morphological changes and shifts in meaning. After independence, in 1972, Kali Besar experienced a physical revitalization, both in the canal, road and several buildings on its side. Now, in the millennial century, Kali Besar continues to be revitalized with various innovations. However, the problem is a tendency for structuring efforts that ultimately have the potential to lose historical value in the region. This article will provide the results on how far the arrangement should be done so as not to change the original character of the Kali Besar area and be able to strengthen the potential of the Old City area as a World Heritage. Also, this study explains the relevance of the historical aspects and Outstanding Universal Value (OUV) in the context of the Kali Kali Revitalization.

\section{Material and Methods}

The study in this article uses historical methods, especially those relating to aspects of urban space, socio-political and revitalization policies. Historical aspects are believed to play a very important role in the formation of city morphology [2]. The form of a city is not just a product but is also a process of accumulation of physical manifestations of non-physical life, 
which is influenced by the system of values and norms that apply in its formation [3]. Therefore, Kali Besar in this article was studied as a physical product and a product of a journey of human life in its time.

The data taken consisted of primary data in the form of visual sources consisting of maps and photos, as well as sources of texts in the form of travel stories and policy data. Maps are obtained from the National Archives of the Republic of Indonesia (ANRI), National Library, Het Nationaal Archief, the Netherlands, Colonial Archief, Gravenhage, and Centrale Bibliotheek Rotterdam 86 N 10. The photos were taken from Collectie_Tropenmuseum and KITLV Leiden. Secondary data is also taken from previous research that has been done in connection with the revitalization of Kali Besar and guidelines from UNESCO on World Heritage.

\section{Results and Discussions}

\section{a. Kali Besar In The Colonial Batavia}

The name Kali Besar has just appeared in the colonial era, which comes from the Dutch language, Groote Rivier. However, the name of Kali Besar then shifted to the name of an area. Before the VOC entered the area where Kali Besar was located, a city called Jayakarta was established as a traditional city consisting of a palace, a square, a market located on the river named Ciliwung River [4]. The city was later destroyed by Jan Pieterszoon Coen, a new city founded in Batavia. Batavia was built following the existence of the Ciliwung River. The river was straightened and turned into a straight and wide canal, The Kali Besar Canal. Kali Besar

Canal became the line for the formation of the City of Batavia and the other canals which was built in stages, starting from the eastern part to the west bank. Figure 1. depicts the construction process of Batavia which shows the change of the Kali Besar canal existence, which is from the winding of Ciliwung River to a large canal, which has been straightened and stretches from north to south. The canal has divided Kali Besar into the two parts of the city which are almost the same size, namely the Greater West and East Kali regions.

Many photos give a picture of Kali Besar's beautiful and crowded face in 1887 and 1993 (Figure 2 and Figure 3). Boats, boats docked, shady and neat trees adorn the banks of Kali Besar [5]. Along the banks of both sides of Kali Besar, there is a pier that used for loading and unloading activities. In this baseline, a series of wards were built for loading and unloading of goods. These wards are closed and some are open. Everything lined up along the two banks of Kali Besar.

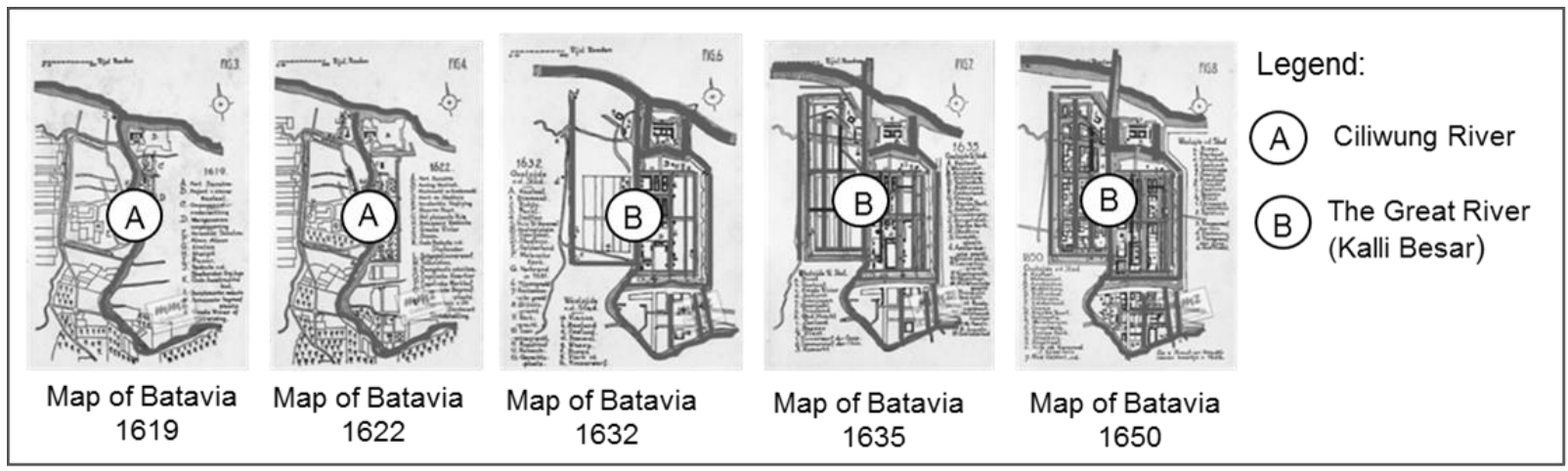

Figure 1. Transformation of Kali Besar, from The River Winding into The Straight Canal Sumber: Breuning (1954) 


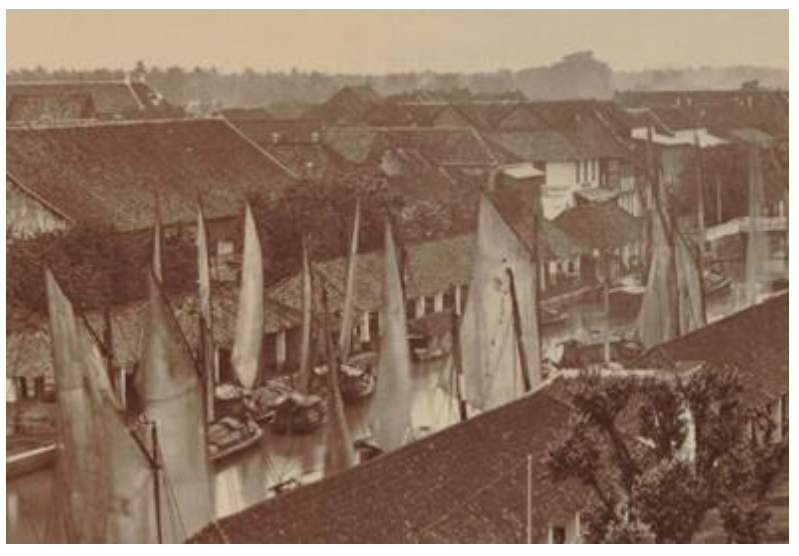

Figure 2. Kali Besar in 1887

Source: http://media-kitlv.nl

Until 1750, the banks of the Kali Besar canal were never closed, either by wood or stone. Along the east and west banks of Kali Besar stand rows of warehouses and other large buildings related to the world of commerce. The warehouses located along Kali Besar are used to store rice, sugar, tea, other merchandise and food for ship supplies. In the northern part of Kali Besar, there is a shipyard to repair ships [5] Kali Besar in colonial Batavia became a determinant for the development of Batavia, both morphologically and socially and economically.

Cities can remind us of the past or known as collective memory. Kali Besar, as an element of the city, has witnessed the existence of a city civilization with canals as a source of life. In the perspective of time dimensions, Kali Besar must be learned and valued as something that is built from time to time. Canal and urban infrastructure in Kali Besar can be used as monuments. that can represent the past of the city as well as its transformation process.

b. Kali Besar Revitalization In Post Colonial After the colonial period, the Kali Besar area was already part of the Old City of Jakarta which was prioritized for revitalization. Kali Besar is a canal of the past that has its uniqueness as an area that has a historical

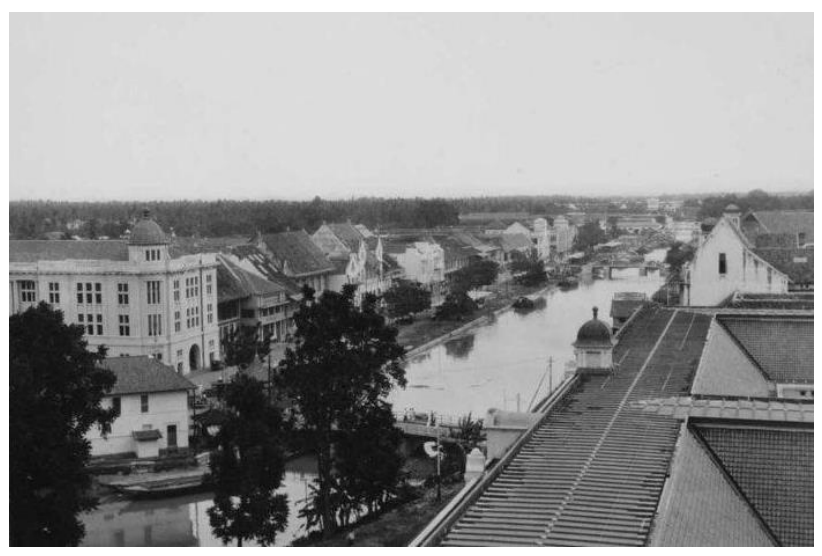

Figure 3. Kali Besar in 1931

Source: http://tropenmuseum.nl

heritage in the form of canals, canal infrastructure and warehouse buildings and offices that still leave their mark. Revitalization of Jakarta's Old City has been carried out since 1972, when Ali Sadikin in 1972, the first Governor of Jakarta, Ali Sadikin, issued an official decree making the Old City a heritage site. This effort began when the inauguration of the former city hall (Stadhuis) became the Jakarta History Museum and was followed by the establishment of several other cultural heritage buildings. This governor's decision is intended to protect the history of the architecture of the city and the Old City can be used as a historical area and where residents can learn the past.

Talking about the revitalization of Kota Tua, it cannot be separated from two important elements of the city, namely private space (the old buildings) and the public space like canals, streets bridge, street, dock, etc. Revitalization of Kali Besar 2016 has been carried out in connection with these two elements, such as the arrangement of pedestrian lanes, community open space bicycle paths, museum buildings, cafes, offices and so on.

The latest work that has been done is the revitalization of Kali Besar which has been carried out since 2016 and completed in 2018. 
This revitalization was carried out based on DKI Jakarta Governor Instruction Number 101 River in the heart of Seoul, Korea, which was of 2016 [9], inspired by the Cheonggyecheon

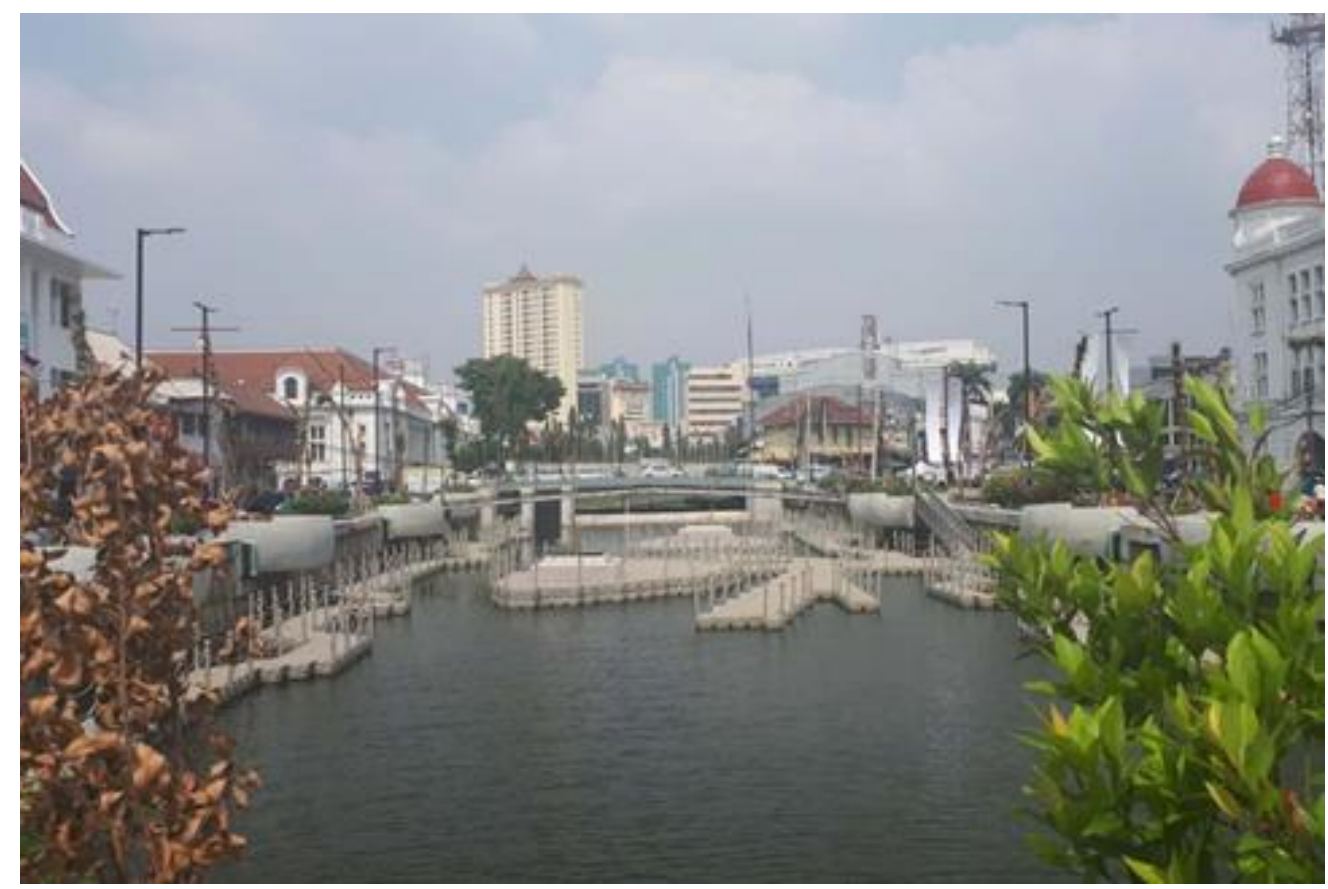

Figure 4. Revitalization of Kali Besar 2018

Source: https://megapolitan.kompas.com/read/2018/07/20/17122491

The design is based on the Water Farm concept, making the canal turn into a garden that adds to the beauty and tourist attraction. In the revitalization, there is a canal water purification program which is carried out through filtration and aeration processes and added with aquaponic planting. Various water plants are planted to add beauty and support the canal with its garden city.

At the same time, the central government was in the process of proposing the Old City Area as one of the UNESCO World Heritage Sites. The optimism of Kota Tua can be included as a World Heritage is quite large, because this region has a lot of high historical heritage. Kali Besar, one of the areas in Kota Tua should be a supporter of its entry as the 2018 World Heritage nominee.

However, this proposal failed and it was alleged that in addition to reclamation, normalization of
Kali Besar as an obstacle was approved as a candidate for world heritage.

\section{c. 'Falsity' In Heritage Revitalization Of Kali Besar}

In principle, the revitalization of a historic area is an attempt to revive a historical area that had died. The Old City area of Jakarta, in general, has experienced revitalization several times, as well as in the Kali Besar area. It has the potential to be proposed as a World Heritage. However, this submission was rejected and it was alleged that there was a "falsity" in the structuring process of Kali Besar. The normalization of Kali Besar is deemed to have changed the originality of the Old City. The first falsity was the use of floating concrete block that covering the canal and it changed the originality of the historic area. The second falsity was the purification or "practice of 
sanitized' process that considered not to solve the problem comprehensively (Figure 5)

Kali Besar is one of the main features of the VOC city plans in the 18th and 19th centuries. Kali Besar was once designed with a specific purpose which was then implemented through an architectural form. This form should be guarded to keep giving a complete story about the occurrence of an activity. The existence of concrete on the canal can be expressed as an effort to eliminate the footprint of the Kali Besar from its past. Kali Besar was once an area that was crowded with various trading activities an5 places where ships were sailing. Kali Besar has a wide cross-section of the canal which reaches around 85 meters [5] illustrates how Kali Besar contains a variety of busy activities. When the landscape of canal is closed by a new element, it will certainly change the image and perception of its past, then a valuable story will disappear.

Beautification is an aesthetic aspect of an urban renewal [6] and now seems to have underlain the arrangement of Kali Besar. Revitalization in the other country that has a different community culture cannot be a full reference. Perceptions on the characteristics of a "beautiful" differing canal of one individual with another individual, according to the context [6]. Trying to beautify and activate an environment is a complex problem which can be helped by legislation [6] and community involvement.

On the other hand, the government must prepare the revitalization management plan of the Kali Besar area involving stakeholders to support the realization of Jakarta's Old City as a World Heritage nomination. An Outstanding Universal Value (OUV) as the main criterion that can help the process of inclusion in the World Heritage List is still very relevant in the context of the revitalization of the Kali Besar area. This OUV can assist in the process of receiving nominations which can explain: 1) what property of site consists of, 2) why it shows the potential of an Extraordinary Universal Value, and 3) how that value can be continued, protected, conserved, managed, monitored and disclosed.

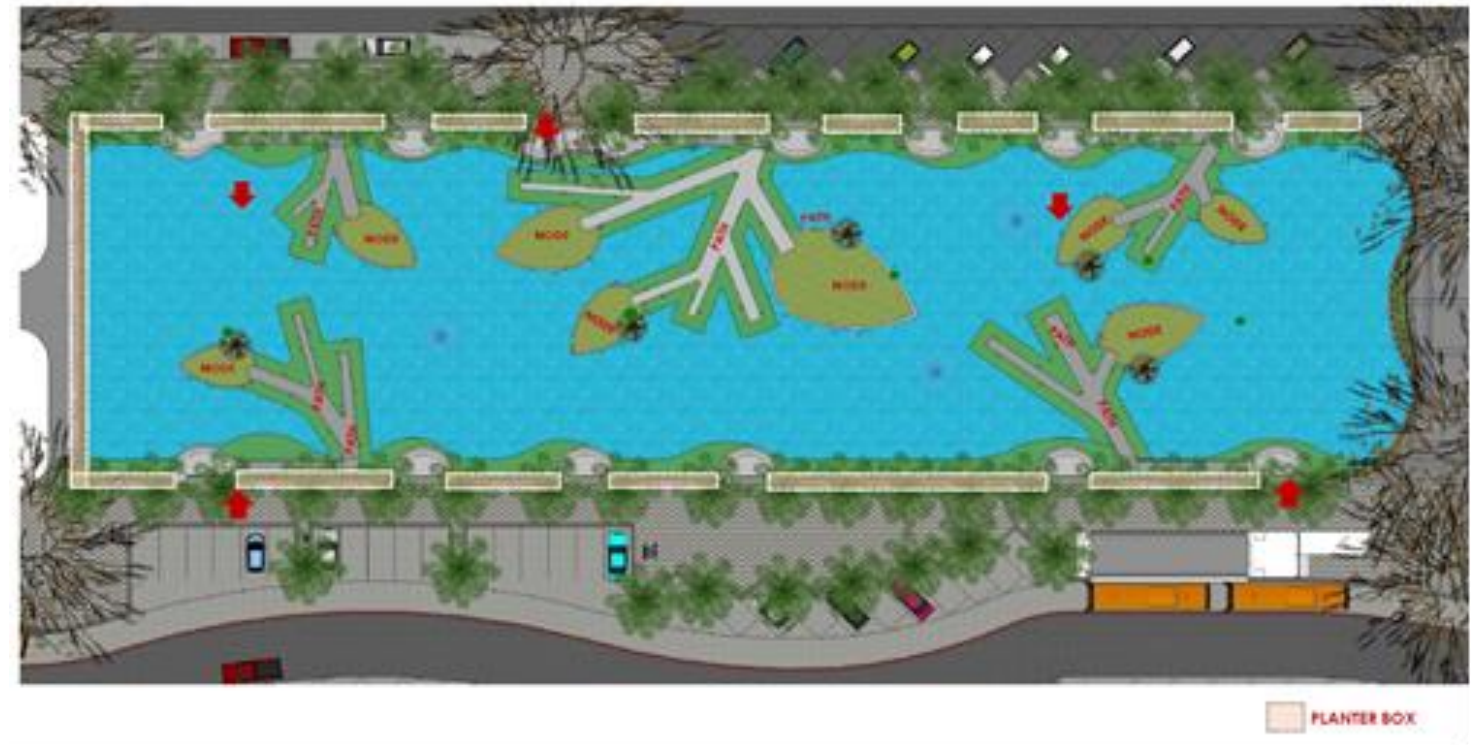

Figure 5. Floating Concrete Block Design, Filterisation, Aerasion and Implemention of Water Farm in Kali Besar Revitalization

Source: UPK Kota Tua Jakarta, 2016 
d. The Importance Of Historical Urban Landscape (Hul) Approaches In The Kali Besar Revitalization

As an area that has a lot of historical richness, Kali Besar is supposed to implement a sustainable urban development process, involving historical elements and values in planning, design, and implementation for its management programs. The Historic Urban Landscape (HUL) approach is a concept in managing a city area when there are many historical or heritage relics. This approach is used comprehensively in understanding the historical urban landscape, especially in areas that experience changes in socio-economic and environmental conditions. Through its road map conservation system can help revitalize Kali Besar in integrating conservation policies and practices of the built environment into international urban development [7].

The planning and management of the Kali Besar area need to recognize the 'dynamic nature of the city' and the complexity of the 'urban heritage' which is manifested in historical layering, values, culture, traditions and experiences, both past and contemporary. The management plan of revitalization must participate the local cultural context values and the urban context which includes topography, hydrology and natural features, existing infrastructure, open spaces, land use patterns and spatial organization, the relationship between visual and perception, and all other elements of urban structure. Another aspect which is certainly not to be ignored is in the form of social and economic processes and nonobject heirloom dimensions related to diversity and identity [6].

To make the management plan and apply as World Heritage candidate, the party must first self-evaluate and do the steps determined by UNESCO, 2011 [8]: 1) Map resources (natural, cultural and human), 2) Reach consensus on values and attributes, 3) Assess Vulnerability to change and development, 4) Integrate in urban development framework, 5) Prioritize actions for conservation and development, 6) Establish local partnerships and management frameworks (Figure 6).

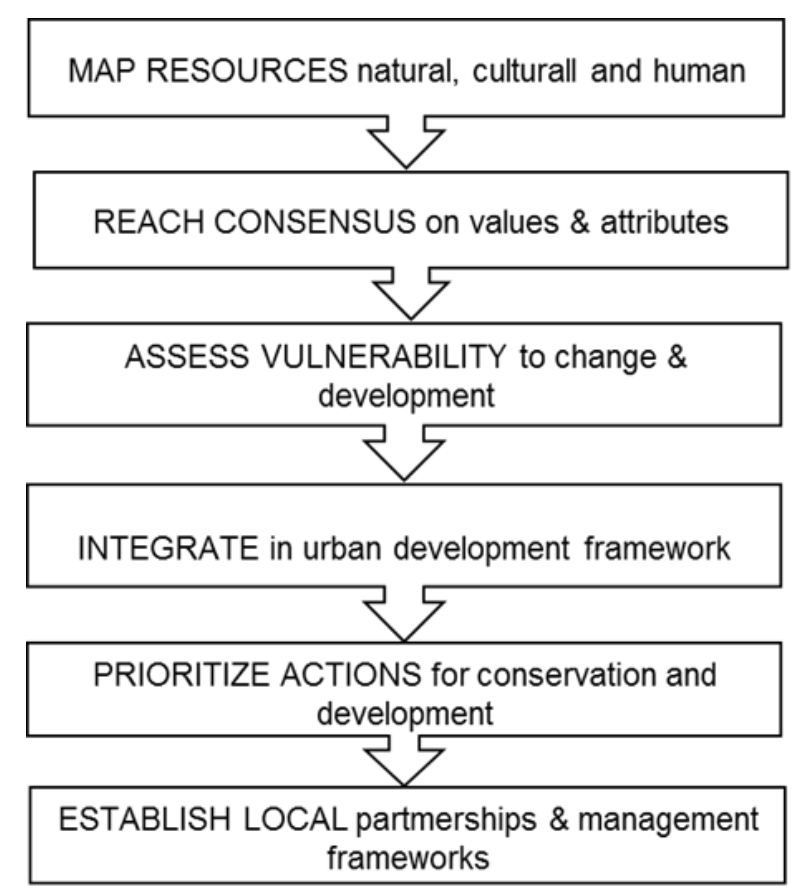

Figure 6. Critical Step of HUL (UNESCO, 2011)

Based on the HUL approach, Kali Besar needs to be designed and managed through 4 tools consisting of 1) Community engagement tools, designed to empower people to identify key values in the city area, articulate their aspirations and visions, set goals and agree on actions to protect their heritage and promote sustainable development, 2) Knowledge and Planning tools, tools in the form of knowledge to enable understanding of urban landscapes, cultural recognition, and assessment and monitoring of change, 3) Regulatory system, to enable effective conservation and wise management of city landscapes, 4) Financial tools, designed to help build capacity, support private and public investment and partnerships [8]. The application of the HUL approach is 
expected to produce a mature management plan and later can be a reference for other areas.

\section{Conclusion}

The Kali Besar area has changed from time to time. In the colonial period, the Kali Besar area was a bustling trading area. The existence of buildings and infrastructure built is in the framework of supporting these activities. After the colonial period ended, by the Indonesian government, specifically the DKI Jakarta government, the Kali Besar area was revitalized and the buildings inside were designated as cultural heritage buildings to maintain their sustainability. However, in 2018, Kali Besar has been revitalized with inspiration from other regions that are not necessarily by the context in Jakarta. Beautification is still considered as the main foundation in its arrangement. Even though to understand urban aesthetics, the interaction and interdependence of the complex environment need to consider not only the physical environment but also the sociocultural environment. The historical value and the high values of a Historic Urban Landscape must be the main references in the process of revitalizing the Kali Besar area.

\section{Acknowledgement}

This paper is a part of a Doctoral thesis plan, entitled "Politics of Space and Discourse of Canals in Batavia: Cleanliness and Dirtiness Transformation during the Colonial Era", which is financially supported by PITTA UI (Indexed International Publication Fund for Students of Universitas Indonesia).

\section{References}

[1] Dewi EP, Kurniawan KR, Ellisa, E. Transformation of Canals in Colonial Batavia. Journal of Architecture and Urban Studies, vol.3, no.1, Jan-Feb-March Edition; 2018.

[2] Mumford L The urban prospect. Harvill Secker;1968. [3] Tallo AJ, Pratiwi Y, Astutik I. Identifikasi Pola Morfologi Kota. Studi Kasus: Sebagian Kecamatan Klojen, Di Kota Malang. Jurnal Perencanaan Wilayah dan Kota, 25(3), 213-227; 2014.
[4] Haris, T. Kota dan masyarakat Jakarta: dari kota tradisional ke kota kolonial (abad XVI-XVIII). Wedatama Widya Sastra; 2007.

[5] Ataladjar TB. Toko Merah: saksi kejayaan Batavia lama di tepian muara Ciliwung: riwayat dan kisah para penghuninya. Dinas Kebudayaan dan Permuseuman DKI Jakarta; 2003.

[6] Carlino GA, Saiz A. Beautiful city: Leisure amenities and urban growth (Working paper through the Urban Economics Lab. Massachusetts Institute of Technology; 2008

[7] Bandarin F, Van Oers R. The historic urban landscape: managing heritage in an urban century. John Wiley \& Sons; 2012

[8] The HUL Guidebook, Managing heritage in dynamic and constantly changing urban environments The World Heritage Institute of Training and Research for the Asia and the Pacific Region under the auspices of UNESCO. UNESCO; 2011. 
International Journal of Built Environment and Scientific Research p-issn: 2581-1347 | e-issn: 2580-2607 | Pg 47 - 54

(This page is intentionally left blank) 